\title{
Relationships between ruminant management and sensory characteristics of cheeses: a review
}

\author{
Jean-Baptiste Coulon ${ }^{a *}$, Agnès DelacroiX-BUCHET ${ }^{\mathrm{b}}$, Bruno MARTiNa ${ }^{\mathrm{a}}$, \\ Antonio PIRISI ${ }^{\mathrm{c}}$ \\ a Unité de Recherches sur les Herbivores, INRA, Theix, 63122 Saint-Genès-Champanelle, France \\ b Unité de Recherches Laitières et Génétique Appliquée, INRA, Domaine de Vilvert, \\ 78352 Jouy-en-Josas, France \\ ${ }^{\mathrm{c}}$ Istituto Zootecnico e Caseario per la Sardegna, Regione Bonassai, 07040 Olmedo, Italy
}

Received 25 July 2003 - Accepted 8 December 2003

Published online 26 March 2004

\begin{abstract}
This review summarises the last 10 years' knowledge established on the relationships between the management of animals (genetics, physiology and feeding) and the sensory quality of cheese. In the production of full-fat raw milk cheese, the cow's breed can modify the texture of cheeses because of differences in fat in dry matter content due to variations in the fat/protein ratio in milk. Within the same breed, large differences in texture and taste were observed between cheeses issued from milk differing by the genetic variant of $\beta$-casein (in dairy cows) or $\alpha_{\mathrm{s} 1}$ - casein (in goats). Except in very early or late lactation, the physiological stage had no significant effect on cheese sensory characteristics. In contrast, mastitis has a well-known negative impact on cheese sensory properties. Feeding dairy cows or goats with corn silage by comparison with hay or grass silage leads to whiter cheeses and sometimes to differences in flavour. Conserving grass as silage, by comparison with hay, has no important effect on cheese sensory characteristics, except on colour, which is yellower with grass silage. Conversely, major differences in sensory characteristics were observed between cheeses made with milk produced by cows fed winter diets (based on hay and grass silage) or turned to pasture in the spring. Several recent experiments showed a significant effect of grass' botanical composition on cheese texture and flavour. Those effects are due to the presence in milk of specific molecules or structures directly induced by feeding (carotenes and terpenes) or produced by the animals (plasmin, fatty acids and casein micellar structures) according to their genetic or physiological characteristics or under the effect of specific diets.
\end{abstract}

\section{Milk / cheese / sensory characteristic / feeding / genetic characteristic}

Résumé - Effets des facteurs de production sur les caractéristiques sensorielles des fromages : une revue. Cette revue fait le point sur les connaissances acquises au cours des 10 dernières années sur les relations entre les facteurs de conduite des animaux (génétiques, physiologiques et alimentaires) et la qualité sensorielle des fromages. Chez la vache, avec des fabrications au lait entier, la race peut modifier les caractéristiques de texture des fromages. Cet effet est lié essentiellement aux différences de composition chimique des laits et donc de gras/sec des fromages. Au sein d'une même race, des différences importantes de texture et de goût ont été observées en fonction des variants génétiques de la caséine $\beta$ (espèce bovine) et surtout $\alpha_{\mathrm{s} 1}$ (espèce caprine). Le stade physiologique n'a un effet marqué sur la couleur, la texture et le goût qu'en tout début ou en toute fin de lactation. En revanche, les mammites ont un effet négatif important sur les caractéristiques sensorielles des fromages. L'utilisation d'ensilage de maïs conduit toujours à des fromages plus blancs, et parfois à des différences de flaveur. Lorsqu'elle est correctement réalisée, la conservation de l'herbe sous forme

\footnotetext{
* Corresponding author: jbc@clermont.inra.fr
} 
d'ensilage comparativement au foin ne modifie pas ou peu les caractéristiques sensorielles des fromages, en dehors de leur couleur, plus jaune avec l'ensilage. Par contre, d'importantes différences de caractéristiques sensorielles sont observées entre des fromages selon que le lait provient de vaches recevant une ration à base d'herbe conservée ou conduites au printemps, au pâturage. Plusieurs essais récents ont mis en évidence un effet de la composition botanique des fourrages ingérés par les vaches laitières sur la texture et la flaveur des fromages. Ces différents effets sont dus à la présence dans le lait de molécules ou de structures issues directement de l'alimentation (carotènes et terpènes) ou produites par l'animal (plasmine, acides gras et structure des micelles de la caséine) en raison de ses caractéristiques génétiques ou physiologiques ou sous l'effet d'une alimentation spécifique.

Lait / fromage / caractéristique sensorielle / alimentation / caractéristique génétique

\section{INTRODUCTION}

The sensory quality of cheese depends on a number of factors linked both to cheese-making technology and to the chemical and microbiological characteristics of the raw material used. These characteristics are themselves dependent on upstream factors (genetic, physiological or dietary...). Those upstream factors have increasingly been the focus of consumers' concern, in particular those related to animal feeding. They take special importance in the case of labelled products (Protected Designation of Origin [PDO], Protected Geographical Indication [PGI], etc.) in which any raw material modification during processing is restricted or prohibited and which claim close links with milk production conditions, some of which being the basis for the "terroir" notion [53]. In cheese production, the relationships between milk production conditions (animal breed and feeding in particular) and cheese characteristics are often evoked by cheese-makers, based on empirical considerations. Until recently, however, very few research studies had been conducted on that topic, due to the difficulty of discriminating between upstream factors and the effects of the cheese-making process per se. In the last few years, several specific studies have been conducted to define those relationships. They were made easier by the development of analytical methods applicable to the sensory characteristics of cheeses and by the improved control of cheese-making parameters. They involved at the same time experimental studies on milk blends from a few animals and more comprehensive approaches, performed in farms or industrial processing plants. In all cases the variation factors linked to animal characteristics or husbandry were monitored and controlled and the cheese-making technology was the same between treatment groups: in most cases the cheeses were made in experimental units and ripened in the same cellar, so as to master and control as well as possible the various cheese-making parameters. After presenting the effects of genetic, physiological and dietary factors on the sensory characteristics of cheeses, this paper will propose a few hypotheses to explain those effects.

\section{EFFECT OF GENETIC CHARACTERISTICS}

A number of studies have assessed the effect of animal genetic characteristics (breed and lactoproteins polymorphism) on milk suitability for cheese-making (coagulation properties and cheese-making performance). Normande or Montbéliarde cows are known to produce more protein-rich milk, better suited for cheese-making than Holstein cows managed under similar conditions [72]: the curd obtained is firmer and the cheese yield is higher [47]. The major part of this effect can be related to the differences in casein content between breeds and to casein genetic polymorphism, and particularly to the frequency of the $\kappa$-casein 
Table I. Effect of breed on sensory characteristics of cheeses [78, 116, 117].

\begin{tabular}{lcccccc}
\hline Trial & \multicolumn{2}{c}{1} & \multicolumn{3}{c}{3} \\
\hline Breed $^{1}$ & HO & MO & HO & MO & HO & MO \\
\hline Milk & & & & & & \\
$\quad$ Fat content $\left(\mathrm{g} \cdot \mathrm{kg}^{-1}\right)$ & $37.0 * *$ & 34.0 & 35.7 & 35.9 & 35.8 & 35.9 \\
$\quad$ Protein content $\left({\left.\mathrm{g} \cdot \mathrm{kg}^{-1}\right)}^{2}\right.$ & $29.4 * *$ & 31.7 & 34.0 & 33.9 & 33.4 & 33.7 \\
& & & & & & \\
Cheese & & & & & & \\
$\quad$ Dry matter $(\%)$ & $52.6 *$ & 51.8 & 55.3 & 55.0 & 54.6 & 54.7 \\
Fat in dry matter $(\%)$ & $53.8 * *$ & 50.9 & 51.7 & 51.6 & 52.7 & 52.9 \\
$\quad$ Yellow index & $28.9 * *$ & 27.3 & 21.7 & 21.4 & $31.4 *$ & 30.4 \\
$\quad$ Firm texture & $3.0 * *$ & 3.6 & 5.1 & 4.9 & $5.2 * *$ & 4.0 \\
$\quad$ Melting texture & $5.2 * *$ & 4.5 & $3.2 *$ & 3.7 & $3.0 * *$ & 4.3 \\
$\quad$ Taste intensity & 5.0 & 5.0 & 5.0 & 5.0 & $5.1 * *$ & 5.6 \\
$\quad$ Odour intensity & 4.5 & 4.8 & 4.2 & 4.1 & 5.2 & 5.3 \\
\hline
\end{tabular}

${ }^{1}$ HO: Holstein; MO: Montbéliarde. $* P<0.05 ; * * P<0.01$.

$\mathrm{B}$ variant. It has indeed been established that those variants, whose frequency varies greatly between breeds, influence certain cheese-making properties of milk [54, 72]. When the effects of casein content and casein polymorphism are included in the data analysis, no significant differences remained between breeds for coagulation properties $[6,72]$. In contrast, much fewer studies have investigated the effects of genetic factors on the sensory characteristics of cheeses.

\subsection{Effect of breed in the various dairy species: cows, goats and ewes}

The few studies undertaken on the effect of breed on the sensory characteristics of cheeses were mainly initiated following questions raised by the PDO cheese channels on the relevance of restricting, as part of their specification requirements, milk production to certain breeds only, and in particular to those traditionally bred locally. Early studies in Auvergne did not elicit any significant sensory differences between Saint-Nectaire cheeses made with milk from either Holstein or Montbéliarde cows [50], except colour, which was yellower with
Holstein milk. Nevertheless that study featured very few sensory descriptors. More recently, milk samples from Holstein and Montbéliarde cows were processed into Saint-Nectaire cheeses under controlled, technologically identical conditions in three trial series (Tab. I). In the first trial, cheese was made from unskimmed milk [78] whereas in the other two trials, milk was standardised through partial skimming before processing $[116,117]$. Highly marked texture differences were noted in the first trial: cheeses made with Holstein cows' milk were less firm and more melting than those made with Montbéliarde milk because of a higher fat in dry matter content due to a higher fat/protein ratio in Holstein cows' milk. Those differences were not found in the other two trials where the milk fat/protein ratio was standardised before processing: on the contrary, in the third trial, cheeses made with Holstein milk were firmer, less melting and more granulous that those made with Montbéliarde cows' milk, regardless of the type of diet. They were also less tasty. In all three trials, the cheeses made with milk from Holstein cows were yellower than the others. A study conducted in Normandy in an industrial cheese-making plant compared 18 Pont l'Evêque soft 
cheeses, including three repetitions, made from batches of milk from Normande or Holstein cows or from blended milk, at two different times of the year (June and September). Some differences appeared before salting (higher fat in dry matter with Normande cows) but the moisture in non-fat cheese was quite similar for all cheeses. The best cheese-making performances were achieved with Normande cows' milk. As to sensory features, although the "Holstein" Pont l'Evêque cheeses were less elastic and stickier in the mouth, they dispatched a stronger yeast smell. Cheeses made with Normande cows' milk were denser. They expressed greater aromatic intensity and complexity, in taste and odour alike. They were characterised by a more aromatic and smoked flavour [41].

In the caprine species, the Norwegians were the first to demonstrate that the preferred "goat" cheese flavour sought by consumers in Northern European cheeses was due to a hereditary feature of goat populations $[8,109]$ and that such a characteristic flavour was also linked to the animal breed. Indeed, several studies confirmed that cheeses made with Norwegian goats' milk had a stronger "goatish" taste than those made with Saanen goats' milk [4, 7, 9, 110].

In the ovine species, to our knowledge, no study has been conducted specifically on the influence of breed on the sensory characteristics of cheeses. A study was conducted in Greece, which involved a dry, hard cheese made from ewes', goats' or cows' milk [67]. Those authors showed that the species influenced lipolysis (higher in cows) and fat matter composition. Ewes' milk cheeses contained more acetic acid whereas cows' milk cheeses contained more butyric acid and medium- and longchain fatty acids. Gonzalez Viñas et al. [51] studied the physico-chemical and sensory characteristics of certain hard cheeses produced in various parts of Spain with milk from different ewe breeds. The results elicited no significant differences in the physico- chemical composition of cheeses according to breed or region. The sensory characteristics of the cheeses were linked to their chemical composition, not to the animal breed.

\subsection{Effect of genetic variants}

The beneficial effect of variant $B$ of $\kappa$ and $\beta$-caseins on the rheological properties of clotted milk and on cheese yield has been evidenced in numerous studies $[35,54,72]$. Variant B reduces clotting and curd-firming times and leads to firmer rennet curd than variant $\mathrm{A}$. Those properties are reflected by the higher cheese-making suitability of milk containing variant $\mathrm{B}$, along with better fat matter retention in the casein network, hence better cheese yield with the same level of useful material (proteins and fat) of processed milk. On the other hand, the effect of those variants on the sensory characteristics of ripened cheeses is still open to question. Comparing the three most frequent haplotypes of $\alpha_{\mathrm{s}}, \beta$ and $\kappa$-caseins $\left(\mathrm{BBB}, \mathrm{BA}^{2} \mathrm{~A}\right.$ and $\mathrm{CA}^{2} \mathrm{~B}$ ) in the Normande breed [54] led to clarifying the cheesemaking value ascribed to variant $B$ of these caseins. During experimental microfabrications of washed-curd cheeses (Saint-Paulintype) using individual milk samples selected on the basis of genotype, filiation and lactation stage as well as chemical composition (identical fat/protein ratio), associating variants $B$ of $\kappa$ and $\beta$-caseins resulted in a much greater increase in cheese yield than could be achieved with each variant taken separately. The BBB curd microstructure was tighter than that of curds $\mathrm{BA}^{2} \mathrm{~A}$ and $\mathrm{CA}^{2} \mathrm{~B}$, primary proteolysis was more extended for the $\mathrm{BA}^{2} \mathrm{~A}$ cheeses $(P<0.01)$ and after ripening, the $\mathrm{BBB}$ cheeses were firmer, less elastic and more brittle than the other ones [90, 91]. In another study, 42 Holstein, Montbéliarde and Tarentaise cows were distributed into two groups according to the genetic variants of $\beta$ and $\kappa$-caseins. The beneficial effect of variant $B$ on the rheological properties of milk was again confirmed although it had no repercussion on the 
Table II. Effect of $\beta$-casein variant $C$ on chemical and sensory characteristics of Beaufort cheese [76].

\begin{tabular}{lccc}
\hline Cheese & Control & Experimental & \\
\hline$\beta$-Cn C (\%) & 13 & 88 & $* *$ \\
Fat in dry matter (\%) & 47.7 & 45.3 & \\
Intact $\beta$-Cn (\%) & 14.8 & 16.6 & \\
Lipolysis (\%) & 0.36 & 0.41 & $* *$ \\
Flavour & & & $* *$ \\
$\quad$ Salty & 4.4 & 5.1 & $* *$ \\
Odour & & & $* *$ \\
$\quad$ Intense & 4.1 & 4.7 & $* *$ \\
$\quad$ Diversify & 3.4 & 4.2 & $* *$ \\
$\quad$ Milk & 3.1 & 3.6 & $*$ \\
Aroma & & & \\
$\quad$ Intense & 5.1 & 5.8 & \\
Animal & 2.3 & 3.0 & \\
$\quad$ Lemon & 1.5 & 1.8 & \\
* $P<0.05 ; * *: P<0.01$ & & &
\end{tabular}

physico-chemical or sensory characteristics of the Saint-Nectaire cheeses made with the corresponding milk samples [118].

The Tarentaise cattle breed, included in the PDO Beaufort specifications, differs from other dairy breeds in its higher frequency of rare variants of $\alpha_{\mathrm{s} 2}, \beta$ and $\kappa$ caseins. The cheese-making consequences of this particularity have been explored. This study revealed the originality of variant $C$ of $\beta$-casein, whose frequency was as high as $17 \%$ in the Tarentaise breed, whereas it was nearly non-existent in most other dairy breeds in France [54]. Initial studies were conducted on individual $\beta$ casein $\mathrm{C}(\beta-\mathrm{Cn} \mathrm{C})$ or $\beta$-casein $\mathrm{A}(\beta-\mathrm{Cn} \mathrm{A})$ (a frequent variant in most breeds) cows' milk samples according to a miniature, cooked, pressed cheese-making technology derived from that of Beaufort cheese. Milk behaviour in cheese vats, proteolysis, structure, texture and flavour of $\beta$-Cn $\mathrm{C}$ cheeses were compared with those of $\beta-\mathrm{Cn} A$ cheeses. It appeared that $\beta-\mathrm{Cn} C$ cheeses, which contained less fat and whose structure was irregular (as observed by electronic microscopy), were characterised by a firmer and less elastic structure than $\beta-\mathrm{Cn} \mathrm{A}$ cheeses. $\beta$-Cn $\mathrm{C}$ cheeses tasted different and were more piquant than $\beta$-Cn A cheeses $[32,75]$. To validate these results, Beaufort cheeses were made by the same cheesemaker at the same time in two different vats in a Northern Alps cooperative, in the spring over two consecutive years, either with milk containing high $(80 \%)$ or low $(15 \%)$ proportions of variant $C$ of $\beta$-casein (Tab. II). The sensory analysis of ripened cheeses by a panel of judges elicited no major differences in cheese textures. In contrast, cheeses made with $\beta$-Cn $\mathrm{C}$ milk were saltier, and despatched a stronger, more animal and more lemony flavour. Their smell was also rated as more intense, more diversified and milkier. Another trained panel for sensory analyses working in parallel also found that $\beta-\mathrm{Cn} C$ cheeses exhibited more intense smell and flavour and used the descriptor "pungent" more often to describe the smell of $\beta-\mathrm{Cn} C$ cheeses [76].

Over the last few decades, caprine breed genotyping has revealed the existence of a wide polymorphism on the $\alpha_{\mathrm{s} 1}$-casein locus, associated with outstanding differences in 
Table III. Effect of $\alpha_{\mathrm{s} 1}$-casein variant on sensory characteristics of goats' cheese [36, 55-57, 60, $69,73,96,97,115]$.

\begin{tabular}{lcc}
\hline$\alpha_{s 1}$-casein variant & Strong (A) & Defective (F/O) \\
\hline Fatty acids in triglycerids & & \\
$\quad \mathrm{C}_{4: 0}, \mathrm{C}_{16: 0}, \mathrm{C}_{18: 1}, 4 \mathrm{EtC}_{8: 0}$ & - & + \\
$\quad \mathrm{C}_{8: 0}, \mathrm{C}_{10: 0}, \mathrm{C}_{12: 0}, \mathrm{C}_{14: 0}, \mathrm{C}_{18: 0}, 4 \mathrm{MeC}_{8: 0}$ & + & - \\
Milk & + & - \\
$\quad$ Casein content & + & + \\
Fat content & - & + \\
$\quad$ Lipase activity and free fatty acids content & & + \\
Cheese & - & + \\
$\quad$ Initial lipolysis & - & - \\
Free fatty acids: $\mathrm{C}_{6: 0}, \mathrm{C}_{8: 0}, \mathrm{C}_{9: 0}, \mathrm{C}_{10: 0}, 4 \mathrm{MeC}_{8: 0}, 4 \mathrm{EtC}_{8: 0}$ & - & + \\
$\quad$ Goat aroma & + & + \\
Firm texture & & \\
\hline
\end{tabular}

the casein synthesis rate [56, 73]. Eleven alleles have so far been identified, associated with four synthesis levels described as "high" (alleles A, B $, \mathrm{B}_{2}, \mathrm{~B}_{3}, \mathrm{~B}_{4}$ and $\mathrm{C}$ ), "medium" (E), "low" $(\mathrm{F}, \mathrm{G})$ and "null" $\left(\mathrm{O}_{1}\right.$, $\mathrm{O}_{2}$ ) [55]. This finding was followed by an analysis of the effect of that polymorphism on milk and cheese properties [57]. The results showed that defective mutants $\mathrm{O}$ and $\mathrm{F}$, which lead to reduced proteosynthesis, are associated with a stronger "goat" flavour of the milk and cheeses produced at mid-lactation (April-May), whereas allele A was associated with higher cheese yield and firmer cheese texture (Tab. III). The same phenomenon was observed when comparing pressed or surface-mould soft cheeses - a more traditional technology of the caprine channel - made with milk of both genotypes [36, 60, 69, 96, 97, 115]. In most of these experiments, the characteristics of the cheeses before salting were similar, in particular the moisture in non-fat cheese. However, during the cheese-ripening period, differences tended to decrease. They peaked halfway into ripening in Gouda-type cheeses [36, 60, 69, 96].

Research studies on ovine lactoprotein polymorphism have not been as numerous as in cows or goats. Despite the great interest in specific research in that field, in con- sideration of the importance of processing ewes' milk into cheese, existing studies concern only texture characteristics. In ewes, casein heterogeneity is more marked than that of serum proteins. King [65] was the first to identify a variant (Welsh) of $\alpha_{\mathrm{s} 1}$-casein, now named variant D [20]. The same variant was later detected in various ewe breeds. To date, six variants $(\mathrm{A}-\mathrm{F})$ have been identified for $\alpha_{\mathrm{s} 1}$-casein, the most heterogeneous ewe lactoprotein [101]. $\alpha_{\mathrm{s} 1}$-casein and $\beta$-lactoglobulin ( $\beta$-Lg) have certainly been the lactoproteins most studied in relation to milk composition and, to a lesser extent, to cheese composition. $\alpha_{\mathrm{s} 1^{-}}$ $\mathrm{Cn}$ genotype CC was associated with [99, 101]: higher casein content in milk, smaller micelle diameter and higher clotting capacity. Fat content was lower in those cheeses because of a higher protein/fat ratio in the milk, whereas proteolysis quality differed slightly between cheeses according to genotypes, which could induce texture differences. Genotype $\beta-\mathrm{Lg} \mathrm{BB}$ is associated with low fat in dry matter content in Tuma cheese [40, 105]. In Sarda ewes, Pirisi et al. [100] showed that the genotype $\beta$-Lg AA milk contained more fat and a lower casein/fat content than $\beta-\mathrm{Lg} \mathrm{AB}$ and $\beta-\mathrm{Lg}$ BB milk, which could account for the fat in dry matter content differences noted in the 
corresponding cheeses. In contrast, Recio et al. [106] never found any significant differences in the chemical composition or clotting aptitude of milk between genotypes $\beta$ - $\mathrm{Lg} \mathrm{AA}, \mathrm{AB}$ and $\mathrm{BB}$ in Merinos ewes.

\section{EFFECT OF HEALTH STATUS AND PHYSIOLOGICAL CHARACTERISTICS}

\subsection{Health status}

Mastitis is an inflammatory reaction of the mammary tissue to an infection. It is the most frequent health problem noted in dairy herds. Besides its possible impact on the microbiological quality of milk, linked to the transfer of infectious germs into milk (some of which, such as Streptococcus agalactiae, Staphylococcus aureus and Escherichia coli can be pathogenic to man) mastitis induces major changes in milk chemical composition. Classically, mastitis induces, in cows' milk at least, a decrease in lactose concentration, alterations of the fat globule membrane promoting lipolysis, a reduction in casein content, an increase in soluble protein and enzyme concentrations (plasmin in particular) and modifications of salt balances [31, 88]. These effects of mastitis on milk composition result from a mammary gland dysfunction which is responsible for accurate transfer of blood compounds into milk. The inflammation of the mammary tissue is also characterised by an influx of white blood cells into the mammary gland, responsible for dramatic increase in somatic cell count (SCC) in milk. Somatic cells also possess an enzymatic complex and plasminogen activator activity [125].

The effects of mastitis on clotting and whey drainage as well as on cheese yield have been comprehensively described by a number of authors, in cows' $[5,10,25,52$, $66,88,103$ ], goats' [49] and ewes' milk alike [98, 102]. Milks with high SCC coagulate slowly and drip-dry poorly. They lead to low cheese yield, due to protein and fat losses in whey. Cheese moisture content is higher [52, 92, 103], associated with an increase in the proteolysis rate and a modification of the proteolysis pattern [25, 92].

Concerning the sensory characteristics of cheeses, early results summed up by Munro et al. [88] underline that the milks with high SCC are classically associated with lower overall appreciation and with texture and/or flavour defects of variable importance according to the type of cheese. Grandison and Ford [52], by making cheeses from milk with SCC between 200000 and 2200000 cells $\cdot \mathrm{mL}^{-1}$, showed that the increase in SCC induced a decrease in firmness and elasticity and an increase in stickiness, those differences being themselves correlated with an increase in cheese moisture content. That effect on cheese texture was confirmed by Auldist et al. [5]. Regarding cheese flavour, the low appreciation generally granted [88] was rarely described: in a few studies, high SCC was associated with such taste descriptors as "rancid" and "oxidised", linked to lipolysis [5] or "bitter", linked to proteolysis [25]. Grandison and Ford [52] also evidenced a positive link between SCC and the overall flavour intensity or that of unpleasant flavours.

Comparing ewes' cheeses made with milk with SCC $<500000$ or $>1000000$ cells $\cdot \mathrm{mL}^{-1}$ did not elicit any significant differences in sensory characteristics [98]. More recently, Pirisi et al.'s results [102] again demonstrated that SCC had no effect on either the rheological parameters or lipolysis of cheeses.

On goats' milk, Jaubert et al.'s studies [62] suggest that the "goat flavour" of milk could be partly linked to the SCC: by sorting goats' milk samples according to the "goat" flavour intensity, those authors found that the milk samples whose goatish flavour was the strongest were characterised by lower fat matter content and higher SCC and lipolysis than those whose goatish flavour 
Table IV. Effect of lactation stage on sensory characteristics of Saint-Nectaire cheese [30].

\begin{tabular}{lcccc}
\hline Lactation stage & Early & Middle & Late & \\
Days in milk & $15-45$ & $150-230$ & 300 & \\
\hline Fresh cheese yield & & 14.1 & 15.5 & $* *$ \\
pH & 13.8 & 5.47 & 5.67 & $* *$ \\
Fat in dry matter $(\%)$ & 5.48 & 52.8 & 53.0 & $* *$ \\
Yellow index & 50.0 & 28.7 & 27.5 & $* *$ \\
Firm texture & 30.3 & 5.0 & 4.3 & $* *$ \\
Pleasant odour & 5.1 & 5.5 & 4.6 & $* *$ \\
Taste persistency & 4.9 & 5.0 & 6.0 & $* *$ \\
Taste intensity & 5.4 & 5.0 & 5.8 & $*$ \\
\hline
\end{tabular}

${ }^{1} \mathrm{~kg}$ curd/100 kg milk. $* P<0.05 ; * * P<0.01$.

was less pronounced. Such differences in goatish flavour can be found in fresh crottin-type cheese but are less noticeable in ripened cheeses, where lipolysis is higher. This result has recently been confirmed by Morgan and Gaspard [87] who did not find any significant effects of SCC on the biochemical or sensory characteristics of buchette-type cheeses. So it appears that goats' cheese cheese-making technology factors, ripening methods in particular, may reduce the effects of SCC.

\subsection{Physiological stage}

Animals' physiological stage is a major variation factor for milk components: fat content and composition, protein content, and concentration of minerals or enzymes such as plasmin [29, 43]. These variations induce important modifications in coagulation and cheese-making performance [77].

In areas where production is very seasonal, the cheeses produced when animals are at the end of lactation are frequently described as moister, exhibiting faster proteolysis, with a softer and less elastic texture and pronounced taste defects [71, 77, 93]. In those studies, however, the effects ascribed to the lactation stage were combined with those of season, feeding or SCC, the latter usually being high at the end of lactation.
Kefford et al. [64] and Auldist et al. [5] tried to describe the effect of the lactation stage in parallel with those of feeding and SCC. Both concluded that the reduction in cheese quality noted at the end of lactation was greatly limited when feeding and SCC were well controlled. Coulon et al. [30], working under controlled milk production and Saint-Nectaire cheese-making conditions, managed to totally single out the effect of the lactation stage, as monitored between 26 and 298 d (Tab. IV). Cheeses made with early lactation milk were more yellowish and exhibited a lower fat in dry matter than others. Cheeses made with late lactation milk were stickier, more melting, less firm and less granulous than those made in early or mid-lactation. Their taste was more intense, persisting, acid and bitter. Their overall appreciation was globally rated lower than others. Although those differences were significant, they were only noticeable at the very end of lactation. In practice, this factor will only be consequential under specific conditions of very clustered calvings or when other factors like SCC are associated with late lactation stages.

\section{EFFECT OF DIETARY FACTORS}

So far, studies on the effect of animal feeding on dairy product quality have mainly involved the influence of nutrient input and of the main feeding types on the 
concentrations of the main milk components (proteins and fat) [27, 111]. These variations may be highly consequential to cheese-making performance [120] and also to certain sensory characteristics, texture in particular (Delacroix and Martley, unpublished). On the other hand, apart from the well-known effect of certain plants (cabbage, garlic and onion) on milk or cheese flavour [46, 114], the specific effect of feeding types per se, forage in particular (preservation method and quality, and floristic diversity) has been little studied. However, it exists a number of empirical observations about these effect [114]. Some cheesemakers have thus frequently reported differences in the sensory characteristics of cheeses according to the type of forage fed to animals. These reports were backed up by global studies aimed at analysing the sensory characteristic diversity of a given type of cheese and paralleling that diversity with the conditions under which the milk and cheeses were produced. Martin and Coulon [77], in farm Reblochon producers, found that differences in cheese sensory characteristics could, under certain cheesemaking conditions, be associated with differences in forage types (hay or pasture). Likewise, in the Comté region, Monnet et al. [86] found evidence of associations between the floristic typology of pastures and the sensory typology of cheeses. Bérodier [12] showed that botanical diversity could be associated with more diversified and numerous cheese aromas. On the plant scale, differences in sensory properties were also found between cheeses made with bulk milk from different groups of farms differing by their herd management system $[2,81]$. More recently, to explain these differences, experimental studies have been initiated to analyse the specific effect of forage types, preservation method and botanical diversity.

\subsection{Effect of the type of diet and grass preservation method}

The effect of using maize silage in the diet was tested in studies that compared cheeses obtained with milk from cows fed exclusively with maize silage or with grassbased rations given in the form of hay [116] or silage [61]. Maize led to cheeses that were whiter, slightly firmer and globally rated lower by tasters, by comparison with grass, regardless of its preservation mode. Toso and Stephanon [112], confirmed those experimental results by comparing Montasio cheeses made with milk from farms that used maize silage or did not. They showed that after two months of ripening, the cheeses from farms without maize silage were preferred to others, although those differences were less marked after 6 and 12 months of ripening. Regarding goats' cheese, recent results have shown that alfalfa hay led to cheeses with much more intense flavour than maize silage [48]. In ewes, using maize silage increased the butyric spore count but had no consequences on the sensory characteristics of the cheeses [18].

The issue of grass preservation in the form of silage has long been a matter of debate within the PDO cheese channels. Certain specific defects could be recorded when silage was poorly preserved [53, 114], in cooked cheeses in particular, where the presence of butyric spores in silage and in milk may lead to major problems in ripening cheeses (late blowing, poor taste and odour) [38]. Results seem to be different when the quality of silage is good. We conducted a trial [117] where grass from the same sward was cropped on the same day and preserved either in the form of silage (with acid preservative addition) or in the form of hay (barn-dried) (Tab. V). Preservation quality was excellent in both cases and the nutrient supplies to animals were computed so as to be equivalent. SaintNectaire cheeses were made in an experimental cheese-making factory with milk from cows that were fed either type of forage. The cheeses made from silage milk were yellower and slightly more bitter than those made from hay milk. The other chemical and sensory characteristics of the cheeses did not differ between the two treatments. This experimental result was confirmed 
Table V. Effect of forage conservation on chemical and sensory characteristics of cheese [117, 119].

\begin{tabular}{lcccc}
\hline Trial & \multicolumn{2}{c}{1} & & \\
\hline Forage & $\begin{array}{l}\text { Grass } \\
\text { silage }\end{array}$ & Pasture & $\begin{array}{l}\text { Grass } \\
\text { silage }\end{array}$ & Hay \\
\hline Milk & & & & \\
$\quad$ Fat content $\left(\mathrm{g} \cdot \mathrm{kg}^{-1}\right)$ & 36.4 & 37.1 & 35.3 & 36.3 \\
$\quad$ Protein content $\left(\mathrm{g} \cdot \mathrm{kg}^{-1}\right)$ & $28.7 * *$ & 33.6 & 33.6 & 33.5 \\
Cheese & & & & \\
Dry matter $(\%)$ & 52.6 & 52.7 & 54.6 & 54.8 \\
Fat in dry matter $(\%)$ & $54.1^{* *}$ & 50.5 & 52.3 & 52.0 \\
Yellow index & $24.7^{* *}$ & 30.5 & $32.9 * *$ & 29.9 \\
$\quad$ Firm texture & $4.3^{* *}$ & 3.4 & 4.6 & 4.5 \\
Sticky texture & $4.1^{*}$ & 3.5 & 3.1 & 3.3 \\
Taste intensity & $5.0^{* *}$ & 5.6 & 5.4 & 5.3 \\
Odour intensity & 4.6 & 4.4 & 5.2 & 5.2 \\
Pungent odour & $1.3 * *$ & 0.2 & & 3.2 \\
$\quad$ Bitter taste & $1.5 *$ & 1.9 & 3.5 & \\
\hline
\end{tabular}

$* P<0.05 ; * * P<0.01$.

by farm reports [1]. These studies showed that when forage preservation was adequate and the corresponding diets were properly designed, the preservation mode per se had a limited effect on the sensory characteristics of cheeses, except paste colour. It is nonetheless possible that the effect of grass preservation in the form of silage may vary according to the type of cheese. In a recent trial, Verdier-Metz et al. (unpublished) found that giving grass silage instead of hay induced more significant sensory differences in Cantal-type cheeses than in SaintNectaire.

Conversely, major differences in sensory characteristics were observed between cheeses whose milk was produced by cows fed winter diets (based on hay and grass silage) or turned to highland pasture in the spring (Tab. V). Saint-Nectaire cheeses made with pasture milk were yellower, with a less firm texture, stronger taste and less piquant, less sour and less fruity flavour than those made with winter milk [119]. Closely similar results were obtained by Buchin et al. [15] in a trial that compared cheeses made with milk from cows that were given haybased diets or spring pasture. These results confirmed the observations made by farm cheese-makers when dairy cows are turned to pasture. In Norway, according to early studies, it appears that the goatish flavour was less pronounced with milk produced by goats fed in sheds than in pasture [68] whereas Ronningen [109] reported the opposite tendency.

\subsection{Effect of grass botanical composition}

Several trials have been conducted in Europe in recent years to describe and analyse the effect of the botanical diversity of forages fed to animals (either grazed or preserved) on the sensory characteristics of various types of cheeses (Fig. 1).

The first trial [16], conducted in an Abondance cheese-maker's farm, consisted of comparing the characteristics of the cheeses made when the herd successively grazed on the two sides of the same highland pasture (where the botanical composition was very different), then came back to an area of the first side that was fenced off after the first passage. The two series of cheeses made when animals were grazing 


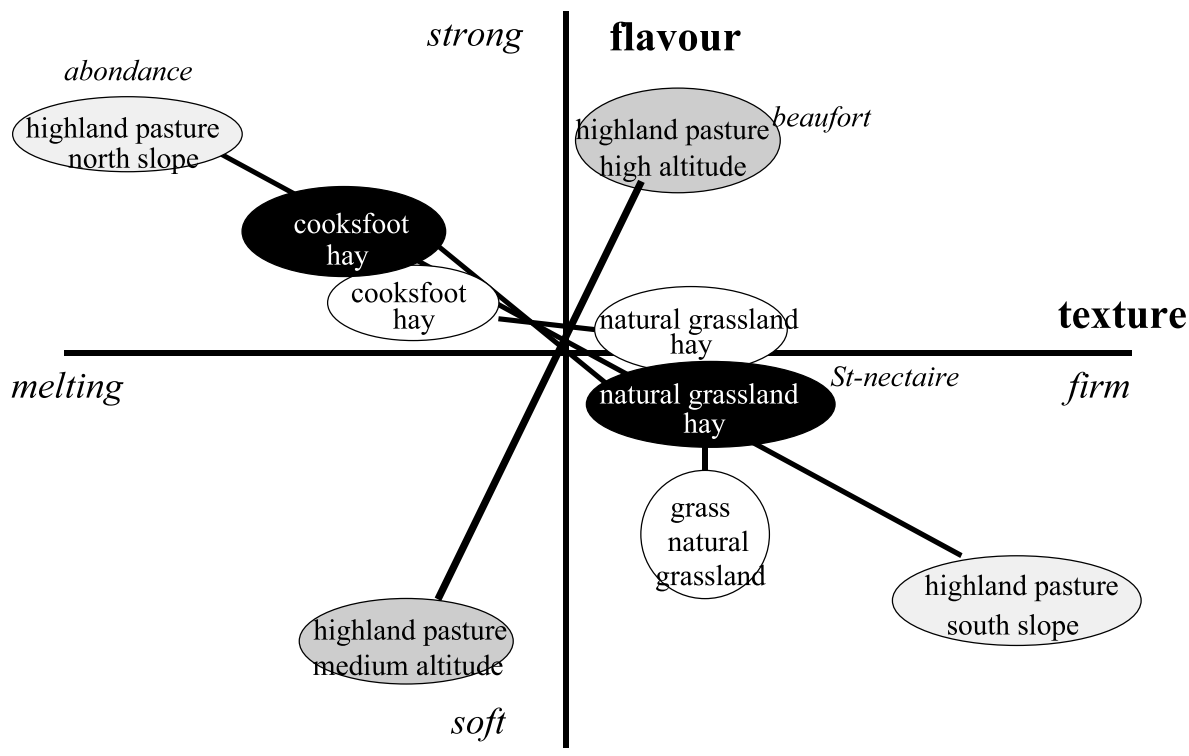

Figure 1. Sensory characteristics differenciation of cheeses according to grass botanical composition (schematic representation of experiments referenced in the text).

on the southerly-exposed side were different from the cheeses of the northern side. The widest differences involved texture: northern-side cheeses were less firm, more melting and pastier. From the aromatic and taste standpoints, northern side cheeses were globally stronger (saltier and bitter, with stables and sweat odours and sour aroma) and those of the southern side were milder, with more developed fruity flavours.

The second trial [79] was conducted in highlands in a Beaufort cheese farm according to the same protocol as the trial one. It revealed differences involving essentially flavour: cheeses from alpine meadows (>2 $200 \mathrm{~m}$ ) were saltier, sharper and more acid than those from medium elevation swards. They expressed more intense and spicy aromas.

The third trial [122] consisted of making uncooked pressed cheeses according to a Saint-Nectaire technology in an experimental farm with milk from cows managed under similar conditions (milking, health status, nutrient inputs and housing) but fed cocksfoot (in the form of hay) or natural Auvergne grass (green or hay). Compared with the cocksfoot cheeses, those cheeses from natural grass were less melting and less bitter, with less developed rancid or mouldy odours. However, the differences were less than those observed in studies with cooked cheeses [16, 79]. Lastly, a recent trial [17] conducted in three farm producers of Abondance, clearly showed that besides differences between producers, major differences could be found within the same producer according to the characteristics of grazing meadows. If the widest differences were between valley and highland pastures, variability subsisted between highland meadows. The main differences involved cheese texture, which was more cohesive, elastic and ductile in valleys than in highlands, and more sandy on nitrophilic and nival meadows than on wet meadows.

These results confirmed and refined those obtained by Bosset et al. [14] with Gruyère-type cheeses made with either valley 
Table VI. Carotenoid content of forages and milk, and corresponding yellow coloration of matured cheeses [28].

\begin{tabular}{lcccc}
\hline Forage & $\begin{array}{c}\text { Bare ground } \\
\text { dried hay }\end{array}$ & $\begin{array}{c}\text { Barn-dried } \\
\text { hay }\end{array}$ & Hay + silage & $\begin{array}{c}\text { Pastured } \\
\text { spring grass }\end{array}$ \\
\hline Forage carotenoids $\left(\mathrm{g} \cdot \mathrm{kg}^{-1} \mathrm{DM}\right)$ & 10 & 20 & 45 & 85 \\
Milk carotenoids $\left(\mu \mathrm{g} \cdot \mathrm{L}^{-1}\right)$ & 75 & 80 & 130 & 220 \\
Cheese yellowness index & 20 & 25 & 28 & 30 \\
\hline
\end{tabular}

or highland milk. In that trial, mountain cheeses tasted stronger than valley ones and were rated as more "animal" and more "pungent".

\section{ORIGIN OF SENSORY DIFFERENCES}

Modifications of the sensory characteristics of cheeses due to upstream factors can depend on different mechanisms: (1) transfer into milk and cheese, without modification, of molecules from feed; (2) protein and fat modifications (content, structure and composition); (3) transfer in cheese of blood or milk endogenous enzymes which modify proteolysis and/or lipolysis during ripening; and (4) microbial ecosystem modifications (composition, dynamics and activity).

\subsection{Direct transfer}

A number of cheese sensory characteristics may be due to certain milk components directly derived from feeding, forages in particular. Many of the Cruciferae, when they are fed in large quantities, give offflavours and a penetrating smell in dairy products due to mustard oil released during digestive fermentation [115]. Cheese colour is also dependent on forage composition. Milk contains variable amounts of pigments. The best known is carotene, which is present in large amounts in green forage and contributes to the yellow coloration of dairy products. Highly sensitive to ultraviolet light, carotene is destroyed during forage drying and preservation, in a manner proportional to light exposure [95]. The type of diet therefore has a marked effect on carotene content in milk, hence on the colour of butter and cheeses [28, 61] (Tab. VI). So cheeses made with spring milk are much yellower than those made with winter milk. Cheeses made in winter with milk from grass silage are far yellower than those made with a hay milk, especially when the hay was left on the ground for a long time. Maize silage, containing very little carotene, produces very white cheeses [116].

Another direct origin of the effect of forage botanical composition on the sensory characteristics of cheeses has long been evoked [42] and involves the effect of terpenes. These plant-specific molecules, when concentrated, have recognised aromatic properties. They abound in certain species, dicotyledons in particular [26, 74]. These molecules very rapidly pass into the milk [124] and are found in cheese in a much greater quantity when the animals are fed dicotyledon-rich natural grass forage than when they are fed concentratebased rations [85], or monospecific forage $[13,15,17,123]$. However, if these molecules may be effective markers of cheeses' origins [14, 26, 45], it appears that changes in their concentration in cheese do not suffice to exert any marked direct effect on cheese flavour $[17,85,119]$.

\subsection{Proteins and fat modifications}

Some of the effects of the upstream factors on cheese sensory properties are due to modifications in the milk protein composition. The poor quality cheeses with high moisture content obtained from mastitis 
milks may be partly explained by the poor clotting and whey drainage abilities of these milks due to composition changes (i.e. increase in whey proteins content and modifications in the salt balance) [31] Whey proteins are also known to retain water more tightly.

The texture differences noted between cheeses made with milk from animals with different casein genotypes occurred as early as during milk coagulation. They were classically explained by differences in the casein micelle structure (proportion of $\kappa$-casein, $\alpha_{\mathrm{s} 1} / \beta$-casein ratio, content in phosphoseryl residues, diameter and calcium mineralisation), which in turn induced variations in fat, water and mineral retention in the casein network. As a result, the microstructure and the rheological properties of rennet curds are modified. The smaller casein micelle diameter gives a denser and firmer casein network [89, 108], which improves fat retention in the coagulum. Such was the case with the association of variant $B$ of $\beta$ and $\kappa$-casein in the Normande cattle breed $[35,91]$ or with the variant $A$ of $\alpha_{s 1}$-casein, compared with defective variants, in goats [107] or with the variant $\mathrm{C}$ of $\alpha_{\mathrm{s} 1}$-casein in sheeps' milk [101]. The example of variant $\mathrm{C}$ of $\beta$-casein in the Tarentaise cattle breed is a good illustration of the mechanisms that can be at the origin of the texture differences noted. The casein micelles of $\beta-\mathrm{Cn} C$ milk were much larger in diameter $(+57 \%)$ and contained less calcium $(-14 \%)$ than the $\beta-\mathrm{Cn}$ A control milk samples, not only because the $\alpha_{\mathrm{s} 1} / \beta$-casein ratio was lower, but also because variant $C$ was less phosphorylated. The result was atypical rennet coagulation behaviour (formation of a slack and fragile network) reflected by softer curd ( $-33 \%$ firmness) with major fat losses in whey. This explained why $\beta-\mathrm{Cn} \mathrm{C}$ cheeses, which were less fatty and whose microstructure was irregular, were characterised by firmer and less elastic texture than $\beta$-Cn A cheeses [32].

Lactoprotein polymorphism also induces variably significant amino acid substitutions or deletions in the sequence of proteins that may affect the kinetics and products of casein proteolysis and generate further modifications of the cheese characteristics. Such was the case with the hydrolysis of $\beta$-casein variant $C$ by plasmin in Beaufort cheese $[75,94]$ or of $\alpha_{s 1}$-casein variant $F$ by chymosin in goats' cheese [97, 113]. The milk proteins that most rapidly undergo cleavage by plasmin are $\beta$ and $\alpha_{\mathrm{s} 2}$-caseins with a higher susceptibility of Lys-X bonds to plasmin activity. Actually, $\beta$-Cn $\mathrm{C}$ differs from $\beta-C n$ A by the substitution Glu37 $(\beta-\mathrm{Cn} A) \rightarrow$ Lys $(\beta-\mathrm{Cn} C)$ which precludes the phosphorylation of Ser 35. The circumstances in which, for $\beta-\mathrm{Cn} C$ and $\beta-\mathrm{Cn} \mathrm{A}$, hydrolysis by plasmin leads to the same types of peptide products, in different molecular ratios, can be considered responsible for different cheese flavours obtained from milk with different haplotypes [75], and in vitro results support these observations [94]. From hydrolysis experiments carried out on $\alpha_{\mathrm{s} 1}$-casein $\mathrm{A}$ and $\mathrm{F}$ at $\mathrm{pH} 5.2$ in the presence of $30 \mathrm{~g} \cdot \mathrm{L}^{-1} \mathrm{NaCl}$, i.e. the conditions encountered in many young goats' cheeses, it was found that variant A was hydrolysed faster than variant $\mathrm{F}$ and the proteolytic pattern differed between the variants [113]. When $\alpha_{\mathrm{s} 1}$-casein has been treated with chymosin, its surface hydrophobicity is decreased markedly and therefore its ability to act as a link in the protein network. Theoretically the $\mathrm{F}$ variant of $\alpha_{s 1}$-casein is more hydrophobic than the $\mathrm{A}$ variant owing to the loss of the hydrophilic cluster of five continuous phosphoseryl residues. The major hydrophobicity and structure-forming properties of $\alpha_{\mathrm{s} 1}$-Cn F could explain differences in casein breakdown, texture and flavour in cheeses made from A and F goats' milks [36, 69, 97].

Milk fat composition (length of the carbon chain and unsaturation degree), closely dependent on animal feeding [21], may also be at the origin of texture and/or flavour differences in butter and cheese [16, 17, 24]. Bugaud et al. [17] observed a close and positive relationship between cheese fracture strain and the proportion of unsaturated 
fatty acids in milk. The lower melting point of these acids may produce a more fluid fatty matter and consequently softer cheeses. Also, certain fatty acids, unsaturated ones in particular, may be degraded by microbial enzymes in the rumen and produce some compounds responsible for cheese aromas $[63,114]$. In other respects, it has been recently demonstrated that the native milk fat globules affect physico-chemical and sensory properties of Camembert cheeses such as meltability, elasticity and colour of the curd [83]. To our knowledge, the effects of genetic factors in milk are still not fully elucidated and from a few observations we can imagine how variable the fat globule sizes are between animal feedings and genotypes ([88], Peyraud, personal communication). Thus, we cannot rule out the possibility of an impact of ruminant management on the global structure of fat globules.

\subsection{Endogenous enzymes}

The content and activity of milk enzymes are also likely to vary according to upstream factors. This is notably the case for proteases such as plasmin, an endogenous enzyme from blood which is resistant to heat treatment, and plays an important role in the ripening of cooked-curd-type cheeses.

The texture differences noted between cheeses issued from late- or middle-lactation milk can be related to increased proteolysis in late lactation, as shown by the increase in $\mathrm{pH}$ and $\gamma$-casein content in these cheeses [30]. This proteolysis is due to plasmin, whose activity increases in late lactation [11], especially when SCC are high [5]. Plasmin is certainly also involved in the texture differences noted between valley and mountain cheeses in Bugaud et al.'s trial [17] or between the north and south sides of the same pasture [16], as its activity was highly variable from one situation to another. Its higher concentration in milk in certain dietary or physiological situations could be due to increased cellular permeability of mammary tissue following a bacterial infection (mastitis), mammary cells' involution (in late lactation) or the intake of certain plant species (Buttercup) present in certain types of meadows only.

The impact of mastitis milk on cheese texture and flavour is partly related to the increase in enzymatic activities in these milks. Addition of mastitis milk to cheese milk has recently been demonstrated to have largely similar effects (on moisture and the proteolytic pattern of cheese) to addition of exogenous plasmin [92]. This reflects that milks rich in SCC have a higher level of plasmin and cell lysosome-derived proteolytic enzymes $[3,52]$ and that SCC also possess a plasminogen activator activity [125].

Modifications have also been observed in the degree of milk or cheese lipolysis according to animal casein genotypes. The physiological mechanisms involved have yet to be identified. Such modifications, however, demonstrate why the aromatic differences typically linked to dairy fat are observed by comparing products selected according to their lactoprotein genetics. In the Tarentaise cattle breed, Beaufort cheeses made with $\beta$-Cn $\mathrm{C}$ milk are more lipolysed and taste more pungent and smell stronger [76]. In goats, milk of defective $\alpha_{\mathrm{s} 1}$ genotypes ( $\mathrm{F}$ or $\mathrm{O}$ ) exhibit higher lipoprotein lipase activity at mid-lactation than the A $\alpha_{s 1}$ genotype and have a stronger goat flavour because it is specifically linked to $\mathrm{C}_{8}$ branched-chain fatty acid release $[23,33$, $34,58,59,69,70,96]$. Nowadays, unpublished observations on milk skimming behaviour (Delacroix-Buchet) and on histological cutting of mammary tissue (Ollivier-Bousquet) suggest that the lack of expression for the gene encoding the $\alpha_{\mathrm{s} 1^{-}}$ casein $(F)$ leads to a dysfunction of the secretion mechanisms of the mammary epithelial cell. This is probably due to a default in the assembly and transit of the casein micelles. The clogging of the endoplasmic reticulum could induce a sort of cell blowing in the apical zone (apocrine secretion) which might result in perturbations in the structure and the secretion of the fat globules, 
as shown by electron microscopy [82]. The specific sensory characteristics of cheeses processed with late lactation milk could also be linked to increased lipolysis in latelactation milk [19]. This lipolysis is not due to the increase in lipoprotein lipase concentration, but mainly to the modification of the fat globule structure [19].

\subsection{Microbial ecosystem}

Lastly, it cannot be ruled out that the upstream factors (type of forage in particular) influence the microbial ecosystem of milk and its activity. A part of the differences in micro-organisms diversity in milk from different farms or plants [37, 39, 44, 84] could be due to animal feeding. It has been recently suggested that terpenes, whose plant-specific origin has been documented, may have an indirect impact on cheese sensory properties by modifying the dynamics of the microbial ecosystem during cheese-making and ripening. This hypothesis results from indirect observation of negative correlation between terpenes and cheese volatile compounds (such as sulphur compounds) originating from protein breakdown by microbial enzymes [16, 17] or directly by addition of terpenes to cheese milk [80]. In addition, the recent findings of Verdier-Metz et al. [121] suggested that some diet effect could be of microbial origin: indeed, they evidenced that the marked differences in flavour of Cantal cheese according to diet observed with raw milk disappeared when milk was pasteurised.

Lastly, concerning the influences of late lactation or mastitis milks (high in SCC) on cheese sensory properties, it has been suggested by Klei et al. [66] that growth of lactic acid bacteria may be inhibited by the antibacterial compounds contained in white blood cells.

\section{CONCLUSION}

Ripened cheese characteristics depend on a lot technological factors. When these factors are not controlled enough, it is dif- ficult to reveal and to interpret the effects of upstream factors. However, most of the experiments reported in this review were carried out in controlled cheese-making conditions, ripening in particular. So, the various results reported here show that animals' characteristics and feeding diets may sensitively modify the sensory characteristics of cheeses. However, those effects can appear at different stages of the cheese-making process (from moulding or only during ripening). They vary according to the type of cheese and interact with the milk transformation processes. So, partial milk skimming to standardise the fat/protein ratio practically obliterates the breed effect on cheese texture. It is therefore likely that certain cheesemaking technologies are better suited than others to express the effects of upstream factors, although the relative quantification of those types of factors has yet to be achieved.

Those effects are due to the presence in the raw material of specific molecules or structures directly induced by feeding (carotenes and terpenes) or produced by the animals (plasmin, fatty acids and casein micellar structures) according to their genetic or physiological characteristics or under the effect of specific diets. In practice, several mechanisms may happen on a single factor, a fact that makes it difficult to interpret their effects. Certain of those molecules (terpenes, carotenes and fatty acids) can also be used to trace feeding [104] and/or confer specific nutritional properties upon dairy products [22].

These results constitute objective data for cheese - especially PDO - channels to envisage the evolution of their milk production specifications. They refer back to the measures to be taken to update or maintain certain animal specificities (e.g., $\beta$-casein variant $C$ in the Tarentaise cattle breed for Beaufort cheese production) or feeding (maintenance of meadow biodiversity) so that cheeses best reflect the originality and diversity of the native land where they are produced. 


\section{REFERENCES}

[1] Agabriel C., Coulon J.B., Journal C., Sibra C., Albouy H., Variabilité des caractéristiques des fromages Saint-Nectaire fermiers : relations avec la composition du lait et les conditions de production, Lait 79 (1999) 291-302.

[2] Agabriel C., Martin B., Sibra C., Bonnefoy J.C., Montel M.C., Didienne R., Hulin S., Effect of production systems on the sensory characteristics of Cantal cheeses: a plantscale study, Anim. Res. (2004) in press.

[3] Andrews A.T., Breakdown of caseins by proteinases in bovine milks with high somatic cell counts arising from mastitis or infusion with bacterial endotoxin, J. Dairy Res. 50 (1983) 57-66.

[4] Anonymous, Flavour in goats' milk products, Meieriposten 65 (1976) 849-850.

[5] Auldist M.J., Coats S., Sutherland B.J., Mayes J.J., McDowell G.H., Rogers G., Effects of somatic cell count and stage of lactation on raw milk composition and the yield and quality of Cheddar cheese, J. Dairy Res. 63 (1996) 269-280.

[6] Auldist M., Mullins C., O’Brien B., O'Kennedy B.T., Guinee T., Effect of cow breed on milk coagulation properties, Milchwissenschaft 57 (2002) 140-143.

[7] Bakke H., Steine T., Eggum A., Relationship between content of free fatty acids and flavour in goat's milk, Meieriposten 65 (1976) 187-194.

[8] Bakke H., Steine T., Eggum A., Flavour score and content of free fatty acids in goat milk, Acta Agric. Scand. 27 (1977) 245249.

[9] Bakkene G., Effect of crossbreeding on quality of goat's milk, Meieriposten 7 (1985) 35-39.

[10] Barbano D.M., Rasmussen R.R., Lynch J.M., Lynch M., Influence of somatic cell count and milk age on cheese yield, J. Dairy Sci. 74 (1991) 369-388.

[11] Benslimane S., Dognin-Bergeret M.J., Berdagué J.L., Gaudemer Y., Variation with season and lactation of plasmin and plasminogen concentrations in Montbéliard cows' milk, J. Dairy Res. 57 (1990) 423-435.

[12] Bérodier F., Crus de Comté, flore des prairies et pratiques agricoles, in: 5th plenary meeting AIR 2039 - COST'95, Du terroir au goût des fromages 27-28 September, Besançon, France, 1997, pp. 186-189.

[13] Bosset J.O., Bütikofer U., Gauch R., Sieber R., Caractérisation de fromages d'alpages subalpins suisses: mise en évidence par
GC-MS de terpènes et d'hydrocarbures aliphatiques lors de l'analyse par «Purge and Trap » des arômes volatils de ces fromages, Schweiz. Milchw. Forschung 23 (1994) 37-41.

[14] Bosset J.O., Jeangros B., Berger T., Bütikofer U., Collomb M., Gauch R., Lavanchy P., Scehovic J., Sieber R., Comparaison de fromages à pâte dure de type gruyère produits en région de montagne et de plaine, Rev. Suisse Agric. 31 (1999) 17-22.

[15] Buchin S., Delague V., Duboz G., Berdagué J.L., Beuvier E., Pochet S., Grappin R., Influence of pasteurization and fat composition of milk on the volatile compounds and flavor characteristics of a semi-hard cheese, J. Dairy Sci. 81 (1998) 3097-3108.

[16] Buchin S., Martin B., Dupont D., Bornard A., Achilleos C., Influence of the composition of Alpine highland pasture on the chemical, rheological and sensory properties of cheese, J. Dairy Res. 66 (1999) 579-588.

[17] Bugaud C., Buchin S., Hauwuy A., Coulon J.B., Texture et flaveur du fromage selon la nature du pâturage : cas du fromage d'Abondance, INRA Prod. Anim. 15 (2002) 31-36.

[18] Cavani C., Bianconi L., Manfredini M., Rizzi L., Zarri M.C., Effects of a complete diet on the qualitative characteristics of ewe milk and cheese, Small Ruminant Res. 5 (1991) 273-284.

[19] Chazal M.P., Chilliard Y., Effect of stage of lactation, stage of pregnancy, milk yield and herd management on seasonal variation in spontaneous lipolysis in bovine milk, J. Dairy Res. 53 (1986) 529-538.

[20] Chianese L., Garro G., Mauriello R., Laezza P., Ferranti P.N., Addeo F., Occurrence of five $\alpha_{\mathrm{s} 1}$-casein variants in ovine milk, J. Dairy Res. 63 (1996) 49-59.

[21] Chilliard Y., Ferlay A., Mansbridge R.M., Doreau M., Ruminant milk fat plasticity: nutritional control of saturated, polyunsaturated, trans and conjugated fatty acids, Ann. Zootech. 49 (2000) 151-205.

[22] Chilliard Y., Ferlay A., Doreau M., Effect of different types of forages, animal fat or marine oils in cow's diet on milk fat secretion and composition, especially conjugated linoleic acid (CLA) and polyinsaturated fatty acids, Lives. Prod. Sci. 70 (2001) 31-48.

[23] Chilliard Y., Ferlay A., Rouel J., Lamberet G., A review of nutritional and physiological factors affecting goat milk lipid synthesis and lipolysis, J. Dairy Sci. 86 (2003) 1751-1770.

[24] Collomb M., Bütikofer U., Spahni M., Jeangros B., Bosset J.O., Composition en acides gras et en glycérides de la matière 
grasse du lait de vache en zone de montagne et de plaine, Sci. Aliments 19 (1999) 97-110.

[25] Cooney S., Tiernan D., Joyce P., Kelly A., Effect of somatic cell count and polymorphonuclear leucocyte content of milk on composition and proteolysis during ripening of Swiss-type cheese, J. Dairy Res. 67 (2000) 301-307.

[26] Cornu A., Carnat A.P., Martin B., Coulon J.B., Lamaison J.L., Berdagué J.L., Solid phase microextraction of volatile components from natural grassland plants, J. Agric. Food Chem. 49 (2001) 203-209.

[27] Coulon J.B., Rémond B., Variations in milk output and milk protein content in response to the level of energy supply in the dairy cow: a review, Livest. Prod. Sci. 29 (1991) 31-47.

[28] Coulon J.B., Priolo A., Influence of forage feeding on the composition and organoleptic properties of meat and dairy products: bases for a "terroir", in: Durand J.L., Emile J.C., Huyghe C., Lemaire G. (Eds.), Multifonction grasslands: quality forages, animal products and landscapes, British Grassland Society, La Rochelle, France, 2002, pp. 513-524.

[29] Coulon J.B., Chilliard Y., Rémond B., Effets du stade physiologique et de la saison sur la composition chimique du lait de vache et ses caractéristiques technologiques (aptitude à la coagulation, lipolyse), INRA Prod. Anim. 4 (1991) 219-228.

[30] Coulon J.B., Verdier I., Pradel P., Almena M., Effect of lactation stage on the cheesemaking properties of milk and the quality of Saint-Nectaire-type cheese, J. Dairy Res. 65 (1998) 295-305.

[31] Coulon J.B., Gasqui P., Barnouin J., Ollier A., Pradel P., Pomiès D., Effect of mastitis type and germ on milk yield and composition during naturally-occuring udder infections in dairy cows, Anim. Res. 51 (2002) 383-393.

[32] Delacroix-Buchet A., Marie C., Comparaison des variants $A$ et $C$ de la caséine $\beta$ des laits de vaches Tarentaises en modèle fromager de type Beaufort. 1- Aptitudes fromagères et rendements en frais, Lait 74 (1994) 343-360.

[33] Delacroix-Buchet A., Lamberet G., Intensity of the spontaneous lipolysis in goat milks and perception of the "goaty" aroma in cheeses, in: 7th Proc. Int. Conf. Goats, Tours, France, 2000, pp. 1019-1020.

[34] Delacroix-Buchet A., Lamberet G., Sensorial properties and typicity of goat dairy products, in: 7th Proc. Int. Conf. Goats, Tours, France, 2000, pp. 559-563.
[35] Delacroix-Buchet A., Lefier D., Nuyts-Petit V., Polymorphisme de la caséine $\kappa$ de trois races bovines françaises et aptitude à la coagulation, Lait 73 (1993) 61-72.

[36] Delacroix-Buchet A., Degas C., Lamberet G., Vassal L., Influence des variants AA et FF de la caséine $\alpha_{s 1}$ caprine sur le rendement fromager et les caractéristiques sensorielles des fromages, Lait 76 (1996) 217-241.

[37] Demarigny Y., Beuvier E., Buchin S., Pochet S., Grappin R., Influence of raw milk microflora on the characteristics of Swisstype cheeses: II. Biochemical and sensory characteristics, Lait 77 (1997) 151-167.

[38] Demarquilly C., Ensilage et contamination du lait par les spores butyriques, INRA Prod. Anim. 11 (1998) 359-354.

[39] Desmasures N., Gueguen M., Monitoring the microbiology of high quality milk monthly sampling over 2 years, J. Dairy Res. 64 (1997) 271-280.

[40] Di Stasio L., Portolano B., Todaro M., Fiandra P., Giaccone P., Finocchiaro R., Alicata M.L., Effect of ovine $\beta$-lactoglobulin phenotype on cheese yield and composition, in: Special issue 9702, Milk protein polymorphism, Int. Dairy Fed. Brussels, Belgium, 1997, pp. 324-327.

[41] Ducy M., Influence du polymorphisme des protéines en fabrication de Pont-l'Evêque, Mémoire de DEA INAPG, Paris, France, 1997.

[42] Dumont J.P., Adda J., Occurrence of sesquiterpenes in mountain cheeses volatiles, J. Agric. Food Chem. 26 (1978) 364-367.

[43] Dupont D., Rémond B., Collin J.C., ELISA determination of plasmin and plasminogen in milk of individual cows managed without the dry period, Milchwissenschaft 53 (1998) 66-69.

[44] Duthoit F., Structure des communautés microbiennes du fromage d'AOC Salers par approche moléculaire : lien avec les caractéristiques sensorielles des fromages. Thèse, Université de Clermont-Ferrand I, France, 2003.

[45] Fernandez C., Astier C., Rock E., Coulon J.B., Berdagué J.L., Characterization of milk by analysis of its terpene fractions, Int. J. Food Sci. Technol. 38 (2003) 445-451.

[46] Forss D.A., Effects of feed on flavour of dairy products, in: New Zeland Dairy Research Institute (Eds.), Milkfat flavour forum, Palmerston North, New Zeland, 1992, pp. 4-16.

[47] Froc J., Gilibert J., Daliphar T., Durand P., Composition et qualité technologique des laits de vaches Normandes et Pies Noires. 1- Effet de la race, INRA Prod. Anim. 1 (1988) 171-177. 
[48] Gaborit P., Raynal-Ljutivac K., Laurent A., Chabosseau J.M., Rouel J., Chilliard Y., Flavour of goat milk and cheeses according to feeding: alfalfa hay or maize silage with oleic sunflower or linseed oil supplementation, in: Durand J.L., Emile J.C., Huyghe C., Lemaire G. (Eds.), Multi-fonction grasslands: quality forages, animal products and landscapes, British Grassland Society, La Rochelle, France, 2002, pp. 562-563.

[49] Galina M.A., Morales R., Lopez B., Carmona M.A., Effect of somatic cell count on lactation and soft cheese yield by dairy goats, Small Ruminant Res. 21 (1996) 251-257.

[50] Garel J.P., Coulon J.B., Effet de l'alimentation et de la race des vaches sur les fabrications de fromage d'Auvergne de Saint-Nectaire, INRA Prod. Anim. 3 (1990) 127-136.

[51] Gonzalez Viñas M.A., Esteban E.M., Cabezas L., Physico-chemical and sensory properties of Spanish ewe milk cheeses, and consumer preferences, Milchwissenschaft 54 (1999) 326-329.

[52] Grandison A.S., Ford G.D., Effects of variation in somatic cell count on the rennet coagulation properties of milk and on the yield, composition and quality of Cheddar cheese, J. Dairy Res. 53 (1986) 645-655.

[53] Grappin R., Coulon J.B., Terroir, lait et fromage: éléments de réflexion, Renc. Rech. Ruminants 3 (1996) 21-28.

[54] Grosclaude F., Le polymorphisme génétique des principales lactoprotéines bovines. Relation avec la qualité, la composition et les aptitudes fromagères du lait, INRA Prod. Anim. 1 (1988) 5-17.

[55] Grosclaude F., Martin P., Casein polymorphisms in the goat, in: Special issue 9702, Milk protein polymorphism, Int. Dairy Fed. Brussels, Belgium, 1997, pp. 241-253.

[56] Grosclaude F., Mahé M.F., Brignon G., Di Stagio L., Jeunet R.A., Mendelian polymorphism underlying quantitative variations of goat $\alpha_{\mathrm{s} 1}$-casein, Génét. Sél. Évol. 19 (1987) 399-412.

[57] Grosclaude F., Ricordeau G., Martin P., Remeuf F., Vassal L., Bouillon J., Du gène au fromage : le polymorphisme de la caséine $\alpha_{\text {s1 }}$ caprine, ses effets, son évolution, INRA Prod. Anim. 7 (1994) 3-19.

[58] Ha J.K., Lindsay R.C., Volatile branchedchain fatty acids and phenolic compounds in aged Italian cheese flavours, J. Food Sci. 56 (1991) 1241-1250.

[59] Ha J.K., Lindsay R.C., Contribution of cow, sheep, and goat milks to characterizing branched-chained fatty acid and phenolic flavors in varietal cheeses, J. Dairy Sci. 74 (1991) 3267-3274.
[60] Heil F., Dumont J.P., Caractéristiques organoleptiques de fromages de chèvre fabriqués à partir de laits contenant des variants génétiques différents de la caséine $\alpha_{\mathrm{s} 1}$, Lait 73 (1993) 559-565.

[61] Houssin B., Foret A., Chenais F., Effect of winter diet (corn vs. Grass silage) of dairy cows on the organoleptic quality of butter and Camembert cheese, in: Durand J.L., Emile J.C., Huyghe C., Lemaire G. (Eds.), Multi-fonction grasslands: quality forages, animal products and landscapes, British Grassland Society, La Rochelle, France, 2002, pp. 572-573.

[62] Jaubert G., Bodin J.P., Jaubert A., Flavour of goat farm bulk milk, in: 6th Proc. Int. Conf. Goats, vol. 2, Beijing, China, 1996, pp. 382-383.

[63] Keen A.R., Wilson R.D., Effect of breed on colour and flavour, in: New Zeland Dairy Research Institute (Eds.), Milkfat flavour forum, Palmerston North, New Zeland, 1992, pp. 50-54.

[64] Kefford B., Christian M.P., Sutherland B.J., Mayes J.J., Grainger C., Seasonal influences on Cheddar cheese manufacture: influence of diet quality and stage of lactation, J. Dairy Res. 62 (1965) 529-537.

[65] King J.B.W., The casein of sheep milk, in: Biochemical polymorphism of animals, INRA, Paris, 1966, pp. 427-431.

[66] Klei L., Yun J., Sapru A., Lynch J., Barbano D., Sears P., Galton D., Effects of milk somatic cell count on cottage cheese yield and quality, J. Dairy Sci. 81 (1998) 1205-1213.

[67] Kondyli E., Katsiari M.C., Differences in lipolysis of Greek hard cheeses made from sheep's, goat's or cow's milk, Milchwissenschaft 56 (2001) 444-446.

[68] Korvald T., Flavour compounds in goat milk and goat cheese. I. Occurrence of flavour in the different fractions of the milk, Meieriposten 47 (1958) 175-179; 183-187; 209-212.

[69] Lamberet G., Degas C., Delacroix-Buchet A., Vassal L., Influence des caractères liés aux allèles $\mathrm{A}$ et $\mathrm{F}$ de la caséine $\alpha_{\mathrm{s} 1}$ caprine sur la flaveur chèvre : fabrications fromagères avec échange de protéines et de matières grasses, Lait 76 (1996) 349-361.

[70] Le Quéré J.L., Pierre A., Riaublanc A., Demaizières D., Characterization of aroma compounds in the volatile fraction of soft goat cheese during ripening, Lait 78 (1998) 279-290.

[71] Lucey J., Cheese-making from grass based seasonal milk and problems associated with late lactation milk, J. Soc. Dairy Technol. 49 (1996) 59-64. 
[72] Macheboeuf D., Coulon J.B., D'Hour P., Effect of breed, protein genetic variants and feeding on cows' milk coagulation properties, J. Dairy Res. 60 (1993) 43-54.

[73] Mahé M.F., Grosclaude F., $\alpha_{\mathrm{s} 1}-\mathrm{Cn}^{\mathrm{D}}$, another allele associated with a decreased synthesis rate at the caprine $\alpha_{\mathrm{s} 2}$-casein locus, Genet. Sel. Evol. 21 (1989) 127-129.

[74] Mariaca R.G., Berger T.F.H., Gauch R., Imhof M.I., Jeangros B., Bosset J.O., Occurrence of volatile mono- and sesquiterpenoids in highland and lowland plant species as possible precursors for flavor compounds in milk and dairy products, J. Agric. Food Chem. 45 (1997) 4423-4434.

[75] Marie C., Delacroix-Buchet A., Comparaison des variants $A$ et $C$ de la caséine $\beta$ des laits de vaches Tarentaises en modèle fromager de type beaufort. 2- Protéolyse et qualité des fromages, Lait 74 (1994) 443 459.

[76] Martin B., Validation en conditions réelles de l'effet du polymorphisme de la caséine $\beta$ des vaches tarentaises sur les caractéristiques du fromage de Beaufort, C.R. d'études GIS Alpes du Nord, Chambéry, France, 1998.

[77] Martin B., Coulon J.B., Facteurs de production du lait et caractéristiques des fromages. II. Influence des caractéristiques des laits de troupeaux et des pratiques fromagères sur les caractéristiques du reblochon de Savoie fermier, Lait 75 (1995) 133-149.

[78] Martin B., Pradel P., Verdier-Metz I., Effet de la race (Holstein/Montbeliarde) sur les caractéristiques chimiques et sensorielles des fromages, Renc. Rech. Ruminants 7 (2000) 317.

[79] Martin B., Buchin S., Hauwuy A., Effet de la nature botanique des pâturages sur les caractéristiques sensorielles du fromage de Beaufort, in: ANFOSC (Eds.), I formazzi d'alpeggio e loro tracciabilita, Bella, Italie, 2001, pp. 230-237.

[80] Martin B., Verdier-Metz I., Cornu A., Pradel P., Hulin S., Buchin S., Dupont D., Lamaison J.L., Carnat A.P., Berdagué J.L., Coulon J.B., Do terpenes influence the flavour of cheeses? II. Cantal cheese, Caseus Intern. 3 (2002) 25-27.

[81] Martin B., Buchin S., Hauwuy A., Laurent P., Effet des systèmes de production sur la qualité sensorielle des fromages. Étude à l'échelle d'une coopérative produisant du Beaufort, Renc. Rech. Ruminants 10 (2003) 237-238.

[82] Martin P., Leroux C., Le gène caprin spécifiant la caséine $\alpha_{\mathrm{sl}}$ : un suspect tout désigné aux effets aussi multiples qu'inattendus,
INRA Prod. Anim, hors série « Génétique moléculaire : principes et application aux populations animales » (2000) 125-132.

[83] Michalski M.C., Gass J.Y., Famelart M.H., Leconte N., Camier B., Michel F., Briard $\mathrm{V}$., The size of native milk fat globules affects physico-chemical and sensory properties of Camembert cheese, Lait 83 (2003) 131-143.

[84] Michel V., Hauwuy A., Chamba J.F., La flore microbienne de laits crus de vache : diversité et influence des conditions de production, Lait 81 (2001) 575-592.

[85] Moio L., Rillo L., Ledda A., Addeo F., Odorous constituents of ovine milk in relationship to diet, J. Dairy Sci. 79 (1996) 1322-1331.

[86] Monnet J.C., Bérodier F., Badot P.M., Characterization and localization of a cheese georegion using edaphic criteria (Jura Mountains, France), J. Dairy Sci. 83 (2000) 1692-1704.

[87] Morgan F., Gaspard C.E., Influence des cellules somatiques sur les qualités technologiques du lait de chèvre et sur les caractéristiques des fromages de chèvre, Renc. Rech. Ruminants 6 (1999) 317.

[88] Munro G.L., Grieve P.A., Kitchen B.J., Effects of mastitis on milk yield, milk composition, processing properties and yield and quality of milk products, Aust. J. Dairy Technol. 39 (1984) 7-16.

[89] Niki R., Arima S., Effects of size of casein micelle on firmness of rennet curd, Jpn. J. Zootech. Sci. 55 (1984) 409-415.

[90] Nuyts-Petit V., Influence des variants génétiques des caséines bovines sur l'aptitude fromagère du lait de vaches de races traditionnelles, Thèse, Université de Compiègne, France, 1991.

[91] Nuyts-Petit V., Delacroix-Buchet A., Vassal L., Influence de trois haplotypes des caséines $\alpha_{s 1}, \beta$ et $\kappa$ fréquents en race bovine Normande sur la composition du lait et l'aptitude à la fabrication fromagère, Lait 77 (1997) 625-639.

[92] O'Farrell I.P., Sheehan J.J., Wilkinson M.G., Harrington D., Kelly A.L., Influence of addition of plasmin or mastitic milk to cheesemilk on quality of smear-ripened cheese, Lait 82 (2002) 305-316.

[93] O'Keeffe A.M., Seasonal and lactational influences on moisture content of Cheddar cheese, Irish J. Food Sci. Technol. 8 (1984) 27-37.

[94] Papoff C.M., Delacroix-Buchet A., Le Bars D., Campus R.L., Vodret A., Hydrolysis of bovine beta-casein $\mathrm{C}$ by plasmin, Italian $\mathrm{J}$. Food Sci. 7 (1995) 157-168. 
[95] Park Y.W., Anderson M.J., Walters J.L., Mahoney A.W., Effects of processing methods and agronomic variables on carotene contents in forages and predicting carotene in alfalfa hay with near-infraredreflectance spectroscopy, J. Dairy Sci. 66 (1983) 235-245.

[96] Pierre A., Le Quéré J.L., Famelart M.H., Riaublanc A., Rousseau F., Composition, yield, texture and aroma compounds of goat cheeses as related to the $\mathrm{A}$ and $\mathrm{O}$ variants of $\alpha_{\mathrm{s} 1}$-casein in milk, Lait 78 (1998) 291-301.

[97] Pirisi A., Colin O., Laurent F., Scher J., Parmentier M., Comparison of milk composition, cheese-making properties and textural characteristics of the cheese from two groups of goats with a high or low rate of $\alpha_{s 1}$-casein synthesis, Int. Dairy J. 4 (1994) 329-345.

[98] Pirisi A., Piredda G., Podda F., Pintus S., Effect of somatic cell counts on sheep milk composition and cheese-making properties, in: Proc. Conference on "Somatic cells and milk of small ruminants", Bella, Italy, 1993, EAAP Publication 77 (1996) 245-251.

[99] Pirisi A., Piredda G., Fraghì A., Papoff C.M., Chianese L., Influence of sheep AA, $\mathrm{CC}$ and DD $\alpha_{\mathrm{s} 1}$-casein variants on milk composition and cheese yield, in: Proc. IDF Seminar on "Milk protein polymorphism", Palmerston North, New Zealand, 1997, pp. 254-258.

[100] Pirisi A., Fraghì A., Piredda G., Leone P., Influence of sheep AA, AB and BB $\beta$-lactoglobulin genotypes on milk composition and cheese yield, in: Proc. 6th Int. Symposium on "Milking of small ruminants", Athens, Greece, 1998, EAAP Publication 95, 1999, pp. 553-555.

[101] Pirisi A., Piredda G., Papoff C.M., Di Salvo R., Pintus S., Garro G., Ferranti P., Chianese L., Effect of sheep $\alpha_{\mathrm{s} 1}$-casein CC, CD and DD genotypes on milk composition and cheese-making properties, J. Dairy Res. 66 (1999) 409-419.

[102] Pirisi A., Piredda G., Corona M., Pes M., Pintus S., Ledda A., Influence of somatic cell count on ewe's milk composition, cheese yield and cheese quality, in: 6th Proc. Great Lakes Dairy Sheep Symposium, Guelph, Canada, 2000, pp. 47-59.

[103] Politis I., Ng-Kwai-Hang K.F., Effects of somatic cell counts and milk composition on the coagulating properties of milk, J. Dairy Sci. 71 (1998) 1740-1746.

[104] Prache S., Priolo A., Tournadre H., Jailler R., Dubroeucq H., Micol D., Martin B., Traceability of grass-feeding by quantifying the signature of carotenoid pigments in herbivores meat, milk and cheese, in:
Durand J.L., Emile J.C., Huyghe C., Lemaire G. (Eds.), Multi-fonction grasslands: quality forages, animal products and landscapes, British Grassland Society, La Rochelle, France, 2002, pp. 592-593.

[105] Rampilli M., Locci F., Bardin M.G., Bolla P., Caroli A., Stabilità termica del siero di latte ovino: Effetto del genotipo $\beta$-lattoglobulinico, Proc. XXVIIth Simposio Internazionale di Zootecnia, Milano, Italia, 1992, pp. 167-174.

[106] Recio I., Fernandez-Fornier A., MartinAlvarez P.J., Ramos M., $\beta$-lactoglobulin polymorphism in ovine breeds: influence on cheese-making properties and milk composition, Lait 77 (1997) 259-265.

[107] Remeuf F., Influence du polymorphisme génétique de la caséine $\alpha_{\mathrm{s} 1}$ caprine sur les caractéristiques physico-chimiques et technologiques du lait, Lait 73 (1993) 549-557.

[108] Remeuf F., Cossin V., Dervin C., Lenoir J., Tomassone R., Relations entre les caractères physico-chimiques des laits et leur aptitude fromagère, Lait 71 (1991) 397-421.

[109] Ronningen K., Causes of variation in the flavor intensity of goat milk, Acta Agric. Scand. 15 (1965) 301-343.

[110] Skjevdal T., Flavour of goat's milk: a review of studies on the sources of its variation, Livest. Prod. Sci. 6 (1979) 397-405.

[111] Sutton J.D., Altering milk composition by feeding, J. Dairy Sci. 72 (1989) 2801-2814.

[112] Toso B., Stephanon B., Effect of ration composition on sensory properties of matured Montasio cheese, Sci. Tecn. LattCasearia 52 (2001) 257-268.

[113] Trujillo A.J., Miranda G., Le Bars D., Delacroix-Buchet A., Proteolytic specificity of chymosin on caprine $\alpha_{\mathrm{s} 1}$-casein A and F, J. Dairy Res. 65 (1997) 233-241.

[114] Urbach G., Effect of feed on flavor in dairy foods, J. Dairy Sci. 73 (1990) 3639-3650.

[115] Vassal L., Delacroix-Buchet A., Bouillon J., Influence des variants AA, EE et FF de la caséine $\alpha_{s 1}$ caprine sur le rendement fromager et les caractéristiques sensorielles de fromages traditionnels : premières observations, Lait 74 (1994) 89-103.

[116] Verdier I., Coulon J.B., Pradel P., Berdagué J.L., Effect of forage type and cow breed on the characteristics of matured Saint-Nectaire cheeses, Lait 75 (1995) 523-533.

[117] Verdier-Metz I., Coulon J.B., Pradel P., Viallon C., Berdagué J.L., Effect of forage conservation (hay or silage) and cow breed on the coagulation properties of milks and on the characteristics of ripened cheeses, J. Dairy Res. 65 (1998) 9-21. 
[118] Verdier-Metz I., Coulon J.B., Pradel P., Viallon C., Albouy H., Berdagué J.L., Effect of the botanical composition of hay and casein genetic variants on the chemical and sensory characteristics of ripened SaintNectaire type cheese, Lait 80 (2000) 361370.

[119] Verdier-Metz I., Coulon J.B., Viallon C., Pradel P., Effet de la conservation du fourrage sur les caractéristiques physico-chimiques et sensorielles des fromages, Renc. Rech. Ruminants 7 (2000) 318.

[120] Verdier-Metz I., Coulon J.B., Pradel P., Relationship between milk fat and protein contents and cheese yield, Anim. Res. 50 (2001) 365-371.

[121] Verdier-Metz I., Martin B., Hulin S., Ferlay A., Pradel P., Coulon J.B., Combined influence of cow diet and pasteurisation of the milk on sensory properties of french PDO cantal cheese, in: CIDIL (Ed.), CDR, 26th IDF World Dairy Congress Congrilait, Paris, 2002.
[122] Verdier-Metz I., Pradel P., Coulon J.B., Influence of the forage type and conservation on the cheese sensory properties, in: Durand J.L., Emile J.C., Huyghe C., Lemaire G. (Eds.), Multi-fonction grasslands: quality forages, animal products and landscapes, British Grassland Society, La Rochelle, France, 2002, pp. 592-593.

[123] Viallon C., Verdier-Metz I., Denoyer C., Pradel P., Coulon J.B., Berdagué J.L., Desorbed terpenes and sesquiterpenes from forages and cheeses, J. Dairy Res. 66 (1999) 319-326.

[124] Viallon C., Martin B., Verdier-Metz I., Pradel P., Garel J.P., Coulon J.B., Berdagué J.L., Transfer of monoterpenes ans sesquiterpenes from forages into milk fat, Lait 80 (2000) 635-641.

[125] Zachos T., Politis I., Gorewit R.C., Barbano D.M., Effect of mastitis on plasminogen activator activity of milk somatic cells, J. Dairy Res. 59 (1992) 461-467. 